humanity in the companionship, often geographically separated, of these two women. "Julia" Scott, who was born in Philadelphia, lived most of her adult life in New York City and first befriended Seton during her marriage to a politician known to the Bayley family. Julia returned to Philadelphia after being widowed, embarking on a correspondence with Seton that lasted until the latter's death. It was during that period of their friendship that Julia's recently married daughter had died on her honeymoon in Europe. Never reproving her friend for her worldly outlook on life, Elizabeth wrote letter after letter sharing with an appreciative Julia her own protracted struggles after the death of her daughter Anna Maria. This is the Elizabeth Bayley Seton one gets to know familiarly in Catherine O'Donnell's portrait of an American saint.

O'Donnell, an associate professor of history at Arizona State University, writes about religion, culture, and politics in early America. She has also authored Men of Letters in the Early Republic, and if her detailed and compelling scholarship in Elizabeth Seton: American Saint is any indication, that volume should be required reading for anyone engaged in the cultural research of the early years of the United States of America.

Joseph S. Rossi, S.J.

Loyola University Maryland

jsrossi@loyola.edu

DOI:10.1163/22141332-00602008-19

\title{
Harvey Markowitz
}

Converting the Rosebud: Catholic Mission and the Lakotas 1886-1916. The Civilization of the American Indian Series 277. Norman: University of Oklahoma Press, 2018. Pp. xvi + 303. Hb, \$34.95.

Harvey Markowitz is associate professor of sociology-anthropology at Washington and Lee University. For many decades he has studied relationships between Catholic missionaries (primarily members of the Society of Jesus and the Sisters of Saint Francis of Penance and Christian Charity) and Sicangu Lakota Sioux Indians of the Rosebud Reservation in South Dakota. He is an adept speaker of Lakota language. He has served prominent institutions such as the National Museum of the American Indian, the National Endowment for the Humanities, and the D'Arcy McNickle Center for American Indian History at the Newberry Library. For ten years (1975-85) he was curator of the Eugene Buechel, S.J. Memorial Sioux Museum and anthropological consultant at Saint Francis Mission on the Rosebud Reservation. Thus, he brings to this, his first book, based on his 2002 dissertation, substantial expertise and mature 
judgment regarding missiological encounters between Christianity and American Indian religions.

Converting the Rosebud draws upon primary and archival documents from the late nineteenth and early twentieth centuries. The volume also makes use of secondary published literature into the 199os. One might wish that Markowitz were more current in referencing the recent, voluminous scholarship about Native American (including Lakota) responses to Christianity. Nonetheless, his work is wise and well worth reading for what it tells us about the missionaries and the Sioux, at least in a particular frame of time.

It is well known that Christian missionaries in the Americas have functioned as agents of colonial policy, even as they have seen themselves as independent, even counter-cultural actors. By the 1850s, as United States policy-makers determined to conquer Plains Indians through treaties, reservations, and assimilative methods of bureaucratic control, aiming to transform Indians "from savage collectivism to civilized individualism" (5), Protestant and Catholic missionaries lined up to "solve the 'Indian problem"' (12) through "Christianization" (12). In 1869, they competed for governmental assignments through President Ulysses S. Grant's Peace Policy to oversee reservation agencies; Catholics felt "shortchanged" (17) when they received only seven agencies as their bailiwicks. Perceiving anti-Catholic bias in the Bureau of Indian Affairs, Catholic leaders created the Bureau of Catholic Indian Missions in 1874 to lobby in Washington, DC and support their own denominational efforts.

By 1886, the missionary bishop of Dakota Territory, Martin Marty, had secured intrepid missionaries-Jesuit priests and brothers and sisters of Saint Francis, both of whom had emigrated to the United States from Germanspeaking lands in response to Otto von Bismarck's Kulturkampf (culture war), which sought "sweeping secularization" (69) of German society and institutions. Markowitz writes that "during the 1870 , thousands of deported or immigrating Jesuits booked passage on ships destined for the United States" (71); many headed for Buffalo, New York, where the so-called "German Province" (72) established a mission. Both orders welcomed Marty's invitation to found a mission and school, and thus, with a small company of two priests, four brothers, and six sisters, Saint Francis came into existence, attracting sixty-five Lakota students. By 1916 (at which point Markowitz concludes his survey), four priests, eleven brothers, and sixteen sisters-along with Jesuit scholastics and native lay helpers—served over three hundred students at St. Francis boarding school and its environs.

Markowitz provides a comprehensive portrait of life at Saint Francis Mission: uniforms, dormitories, required speaking of English, agricultural and domestic work, entertainment, the etiquette of silence, piety, and discipline, the weekly and seasonal liturgies, corporal punishments, and the retrieval of 
runaways. Catechesis focused on the commandments, sins, sacraments, and virtues espoused by the church. The hope was for gradual instillation of Catholic culture over the generations of Lakota to come.

The Sicangus did not reject the Catholic message and cultural innovation. At the same time, they saw little need to abandon their own ways, including habits regarding marriage, economics, and ceremonialism. Most significantly, their religious metaphysics - their sense of "wonderment at a profoundly mysterious universe" (163), their concepts of spiritual essences and potencies, their cosmological frameworks and ritualized quests for kinship throughout the living realm of nature-established a world view through which they perceived Christianity (in its several competing forms). The Catholic missionaries could make demands for religious conversion, however gradual, but as the Sicangus saw it, "they were already provided with a religion of their own" (182). They were willing to adopt "various forms of the 'white man's prayer' in purely utilitarian terms" (186), partially in order to harness the wherewithal of mission institutions for their own purposes of "individual and collective survival" (202). But by and large they did not wish to eschew their traditions.

In his chapter about "Catholicism and Sacred Power" (203), Markowitz delineates several strategies adopted by the Sicangus in responding to the missionary call. Even as the Jesuits tried to inculturate Catholicism among the Rosebud Indians by employing Lakota terminology for Catholic concepts, institutions, and practices (for example, terming Catholic retreats as hanbleceya, the Lakota term for their vision quests), most Lakotas persisted in distinguishing between their religion and Christianity. Some sought whatever spiritual powers they could gain by "participating in the religious gatherings of all of Rosebud's denominations but refusing to affiliate themselves officially with any" (215). Others "decided to convert to Catholicism while clandestinely attending rituals and services of other religions" (215), including those of their own aboriginal faith. Some chose "deathbed' conversion" (216). Others immersed themselves in Catholic sodalities and ceremonial participation in ways that reinforced traditional Lakota societal archetypes. In short, the patterns of religious ecumenism, pluralism, syncretism, compartmentalization, and ambivalence, analyzed in the vast literature about Christian missions and American Indian responses were strongly evident at Saint Francis in the late 180os and early 1900s-right up until the moment in 1916 when unnamed Sicangus burned down the mission, and beyond, to this day.

\section{Christopher Vecsey}

Colgate University

cvecsey@colgate.edu

DOI:10.1163/22141332-00602008-20 